\title{
Pola Asuh Orang Tua dalam Penguatan Pendidikan Karakter Anak (Studi Kasus pada Anak TKW di SDN Pidodo Kecamatan Karangtengah)
}

\author{
Salafuddin $^{1}$, Santosa ${ }^{2}$, Slamet Utomo ${ }^{3}$, Sri Utaminingsih ${ }^{4}$ \\ ${ }^{1}$ Magister Pendidikan Dasar Universitas Muria Kudus \\ Email: salafuddinsaja@gmail.com \\ ${ }^{2}$ Magister Pendidikan Dasar Universitas Muria Kudus \\ Email: santosa@umk.ac.id \\ ${ }^{3}$ Program Studi Bahasa Inggris Universitas Muria Kudus \\ Email: Slamet.utomo@umk.ac.id \\ ${ }^{4}$ Magister Pendidikan Dasar Univeristas Muria Kudus \\ Email: sri.utaminingsih@umk.ac.id
}

\begin{abstract}
ABSTRAK
Ibu sebagai madarasah yang pertama dan utama harus bisa menjadi sosok panutan bagi anakanaknya. Namun bagaimana kalau ibu pergi meninggalkan rumah dan bekerja menjadi TKW. Pengasuhan anak akhirnya dilakukan oleh ayah atau orang tua lain. Penelitian ini bertujuan untuk mendeskripsikan pola asuh orang tua dalam penguatan pendidikan karakter pada keluarga TKW. Penelitian ini menggunakan metode kualitatif deskriptif. Sumber data dalam penelitian ini adalah ayah, kakek, nenek, anak, saudara terdekat, tetangga terdekat dan guru yang mengajar anak di SDN. Teknik pengumpulan data menggunakan teknik wawancara mendalam, observasi dan dokumentasi. Analisis dengan pengumpulan data, reduksi data, sajian data dan penarikan kesimpulan. Keabsahan data menggunakan teknis triangulasi metodologis, yaitu menggunakan beragam metode untuk mengkaji problem tunggal. Hasil penelitian terdapat tiga macam pola asuh yang digunakan oleh orang tua dalam memberikan pengasuhan pada anak TKW. Ada tiga macam pola asuh (1) Pola asuh otoriter dengan ditandai sikap orang tua yang bertindak keras, diskriminatif. harus patuh terhadap perintah orang tua, anak dari orang tua yang otoriter memiliki lebih banyak tekanan (2) Pola asuh demokratis yaitu orang tua bersikap terbuka, percaya dengan kemampuan anak, selalu mengontrol tindakan anak sehingga anak terpacu untuk menjadi pribadi yang lebih baik. (3) Pola asuh permisif yaitu orang tua tidak peduli dengan tindakan anaknya, tidak mengontrol tindakan anaknya sehingga anak berperilaku sesuai keinginan sendiri dan tidak mempunyai rasa tanggung jawab. Strategi yang digunakan oleh orang tua dalam penguatan pendidikan karakter adalah dengan nasehat, teladan dan pembiasaan.
\end{abstract}

Kata Kunci: Pola Asuh, Pendidikan Karakter, Anak TKW

\section{ABSTRACT}

The mother as the first and foremost attend should be a figure of role model for her children. But what if the mother goes to leave the house and work as a TKW. Parenting is finally done by a father or another parent. This research aims to describe the parent's foster pattern in strengthening character education in the TKW family. This research uses qualitative methods of descriptive. The data sources in this study are fathers, grandfathers, grandmothers, children, nearby siblings, nearby neighbors and teachers teaching children at SDN. Data collection techniques use in-depth interview techniques, observations and documentation. Analysis with data collection, data reduction, data feeds and withdrawal of conclusions. The validity of the data uses methodological triangulation technically, which is using a variety of methods to examine a single problem. The results of the study were three kinds of foster patterns used by parents in providing parenting to TKW children. There are three kinds of foster pattern (1) an authoritarian foster pattern with marked attitudes of parents acting hard, discriminatory. Must obey the order of the parents, the child of an authoritarian parent has more pressure (2) a democratic foster pattern that is an open parent, believing in the ability of a child, always controlling the child's actions so that the child is encouraged to be a better person. (3) The permissive parenting pattern is that parents do not care about their child's actions, do not control their child's actions so that they behave in their own way and have no sense of responsibility. The strategy used by parents in the strengthening of character education is by counsel, exemplary and habituation.

Keywords: Foster Pattern, Character Education, TKW Children. 


\section{PENDAHULUAN}

\section{Latar Belakang}

Orang tua adalah orang yang sangat penting dalam proses pengasuhan dan pendidikan anak. Pola dan kualitas pengasuhan anak maupun pendidikanya di lingkungan keluarga sangat ditentukan oleh kualitas dan kesiapan oleh keluarga (suami-isteri) sendiri untuk melaksanakan tugas-tugasnya, kususnya melalui peran edukasi (pendidikan). Dilingkungan keluarga peran perempuan sangat dominan (Fuaduddin TM, 1999). Selaku orang yang paling bertanggung jawab dalam pendidikan keluarga maka hendaknya orang tua bisa menjadi contoh sikap yang terbaik atau model yang pantas ditiru bagi anak-anaknya.

Orang tua bertanggung jawab terhadap pendidikan anak dalam keluarga. Segala sesuatu sekecil apapun yang telah dikerjakan dan diperbuat oleh siapapun, termasuk orang tua akan dipertanyakan dan dipertanggung jawabkan di hadapan Allah SWT.(Syaiful Bahri Djamarah 2014)

Lingkungan keluarga merupakan lingkungan pendidikan yang pertama, karena dalam lingkungan keluarga inilah anak pertama kali memperoleh pendidikan dan bimbingan. Dalam perundang undangan disebutkan bahwa keluarga memberikan keyakinan agama, menambah nilai-nilai moral, etika, dan kepribadian estetika, serta meningkatkan pengetahuan dan keterampilan peserta didik dalam rangkai mencapai tujuan pendidikan nasional. Pendidikan keluarga dalam pasal 27 ayat (1) UU Sisdiknas dinyatakan bahwa pendidikan keluarga adalah jalur pendidikan informal. Setiap anggota keluarga mempunyai peran, tugas, dan tanggung jawab masingmasing, dan mereka memberi pengaruh melalui proses pembiasaan pendidikan di dalam keluarga.

Pengertian keluarga dapat ditinjau dari dimensi hubungan darah dan hubungan sosial. Keluarga dalam dimensi hubungan darah adalah suatu kesatuan sosial yang diikat dengan hunbungan darah antara satu dengan yang lainya.(Moh. Sochib.2010:17). Berdasarkan dimensi hubungan darah ini, keluarga dapat dibedakan menjadi keluarga besar dan keluarga inti. Sedangkan dalam dimensi hubungan sosial, keluarga adalah suatu kesatuan sosial yang diikat oleh adanya saling berhubungan atau interaksi dan saling mempengaruhi antara satu dengan yang lainya.

Dalam pengertian psikologis, keluarga adalah sekumpulan orang yang hidup bersama dalam tempat tinggal bersama dan masingmasing anggota merasakan adanya pertautan batin sehingga terjadi saling mempengaruhi, saling memperhatikan, dan saling menyerahkan diri. Soelaeman dalam Moh. Shochib (2014:17) sedangkan dalam pengertian pedagogis, keluarga adalah "satu" persekutuan hidup yang dijalin oleh kasih sayang antara pasangan dua jenis manusia yang dikukuhkan dengan pernikahan, yang bermaksud untuk saling menyempurnakan diri. Dalam usaha saling melengkapi dan saling menyempurnakan diri itu terkandung perealisasian peran dan fungsi sebagai manusia.

Keluarga memiliki peran sebagai media sosialisasi pertama bagi anak. Peran inilah yang membuat orang tua memiliki tanggung jawab terhadap perkembangan fisik dan mental anak. Di keluarga anak mulai dikenalkan terhadap ajaran-ajaran yang sesuai dengan kaidah-kaidah yang berlaku dalam agama maupun masyarakat. Semua anak aktivitas anak dari mulai perilaku dan bahasa tidak terlepas dari perhatian dan binaan orang tua. (Aziz Obi Faizal. 2017)

Keutuhan orang tua (ayah ibu) dalam sebuah keluarga sangat dibutuhkan dalam membantu anak untuk memiliki dan mengembangkan dasar-dasar disiplin diri. Keluarga yang utuh memberikan peluang besar bagi anak untuk membangun kepercayaan terhadap kedua orang tuanya, yang merupakan unsur esensial dalam membantu anak dalam memiliki dan memgembangkan dasar-dasar disiplin diri. Kepercayaan dari orang tua yang 
dirasakan oleh anak akan mengakibatkan arahan, bimbingan, dan bantuan yang diberikan orang tua kepada anak akan menyatu dan memudahkan anak unuk menangkap makna dari upaya yang dilakukan.(Moh. Sochib. 2014).

Menurut Hurlock orang tua tunggal adalah orang tua yang telah menduda atau menjanda entah bapak atau ibu, mengasumsikan tanggung jawab untuk memelihara anak setelah kematian pasanganya, perceraian atau kelahiran anak diluar nikah.

Hummer dan Tunner menyatakan bahwa "A Single parent family consist of one parent with dependent children living in the same household". Pelmutter dan Hall menyatakan bahwa single parent adalah " Parent without partner who continu to raise their children".

Berdasarkan beberapa pendapat diatas dapat dinyatakan bahwa, orang tua tunggal adalah orang tua yang mengasuh anak tanpa pasangan baik itu ayah atau ibu dalam mengasuh, membesarkan dan mendidik anak serta mencukupi kebutuhan anak secara sendirian. Dalam hal ini orang tua tunggal mempunyai peran ganda yaitu sebagai sosok seorang ayah sekaligus seorang ibu. Selain itu oarng tua tunggal juga mempunyai tugas selain mencari nafkah juga mengasuh anak yang kedua-duanya harus berjalan secara seimbang agar kebutuhan anak baik jasmani maupun rohani bisa terpenuhi.

Pembentukan budi pekerti yang baik adalah tujuan dalam pendidikan kita. Karena dengan budi pekerti itulah tercermin pribadi yang mulia. Sedangkan pribadi yang mulia itu adalah pribadi yang utama yang ingin dicapai dalam mendidik anak dalam keluarga. Namun sayangnya tidak semua orang tua dapat melakukanya. Banyak faktor yang menjadi penyebabnya, misalnya orang tua yang sibuk dan bekerja keras siang dan malam dalam hidupnya untuk memenuhi kebutuhan materi anak-anaknya, waktunya dihabiskan di luar rumah, jauh dari keluarga, tidak sempat mengawasi perkembangan anaknya, dan bahkan tidak punya waktu utnuk memberikan bimbingan, sehingga Pendidikan bagi anakanaknya terabaikan.

Fenomena yang saat ini semakin merambah dan nyaris membudaya yaitu pekerjaan ibu diserahkan kepada orang lain. Misalnya pengasuhan anak tidak dilakukan oleh ibu kandungnya. Padahal fungsi dan keutamaan bekerja di rumah bagi seorang ibu berdampak pada anak dan suaminya. Hubungan mereka bertambah dekat sebab semua terkonsentrasi pada keluarga. Semua jadi rindu pulang ke rumah. Kenyataan ini akan menjadi teladan jika anak sudah berumah tangga kelak. Nibras OR Salim (1997)

Bekerja di luar rumah terutama ke luar negeri tentu saja berpengaruh terhadap proses kelangsungan kehidupan rumah tangga. Karena dengan kegiatan yang mereka lakukan diluar rumah, berarti mereka telah meninggalkan waktu di dalam keluarga untuk bekerja. Relasi sosial dengan suami dan anggota keluarga lainya pun berubah. Tidak jarang juga menimbulkan kesalahpahaman dengan suami dan keluarga. Termasuk dalam pengasuhan anak.

Permasalahan anak bukanlah permasalahan yang mudah, dalam prakteknya banyak keluarga TKW yang anaknya tinggal bersama ayah, nenek, bibi, paman atau saudara. Hal ini yang mengakibatkan anak kurang perhatian dan kasih sayang sehingga mereka menjadi nakal dan susah diatur. Seperti halnya ketika di sekolah beberapa anak TKW berpakaian kurang tertib, tidak disiplin, tidak mengerjakan tugas, suka menganggu teman dan suka bergurau kalua diajar.

Fenomena yang terjadi di desa Pidodo Kecamatan Karangtengah Kabupaten Demak adalah sebagian orang tuanya kurang maksimal dalam pendidikan anak, khususnya dalam pendidkan karakter yang disebabkan karena salah satu orang tuanya bekerja sebagai tenaga kerja Indonesia (TKI). Hal tersebut mengakibatkan anak kurang mendapat kasih sayang, kurang pengawasan dan bimbingan dari 
orang tua mereka. Akibat dari ibu yang menjadi tenaga kerja wanita (TKW) ke luar negeri, maka peran orang tua mereka tidak berperan secara seimbang dalam mengasuh sehingga berdampak pembentukan karakter anak.

\section{Tujuan dan Manfaat Penelitian}

1. Mendeskripsikan pola asuh orang tua dalam penguatan pendidikan karakter anak yang sekolah di SDN Pidodo Kecamatan Karangtengah Kabupaten Demak.

2. Mendeskripsikan strategi pengasuhan orang tua dalam pembentukan karakter anak di SDN Pidodo Kecamatan Karangtengah Kabupaten Demak.

3. Mendeskripsikan hambatan-hambatan yang terjadi dalam penguatan pendidikan karakter anak pada keluarga TKW yang anaknya sekolah di SDN Pidodo Kecamatan Karangtengah Kabupaten Demak baik itu hambatan secara internal maupun hambatan eksternal.

\section{Manfaat Penelitian}

1. Secara teoritis

Penelitian ini dapat memberikan informasi, mengenai upaya ayah dalam pembentukan karakter pada anak terutama yang berkenaan dengan model, strategi dan cara yang dapat diciptakan serta dapat menjelaskan tujuan dari pengasuhan ayah dalam pembentukan karakter anak.

Dengan demikian diharapkan dapat membantu mengembangkan teori pendidikan umum, yaitu teori yang berkenaan pengembangan teori pola asuh orang tua dan pendidikan karakter anak.

2. Secara Praktis

a.Untuk lembaga pendidikan sebagai bahan masukan mengenai pentingnya pengasuhan orang tua terhadap anaknya dalam membentuk karakter

b.Peneliti

Dapat memberikan wawasan betapa pentingnya pengasuhan terhadap anak dalam pembentukan karakter dan dapat menjadi pedoman pengasuhan yang baik terhadap anaknya.

c. Bagi Masyarakat

Penelitian memberikan wawasan atau pengetahuan informasi kepada masyarakat, bahwa dengan pengasuhan orang tua yang baik terhadap anak akan berdampak dalam pembentukan karakter anak. Untuk itu oaring tua hendaknya orang tua mengasuh anak dengan memberi contoh atau model yang baik agar anak juga meniru sifat dan karakter yang baik pula.

\section{METODE PENELITIAN}

\section{Lokasi Penelitian}

Penelitian dilakukan di SDN Pidodo Kecamatan Karangtengah Kabupaten Demak di daerah tersebut terdapat lima keluarga TKW yang anaknya sekolah di SDN Pidodo Kecamatan Karangtengah Kabupaten Demak yang pola asuhnya dilakukan oleh ayah, nenek, paman, bibi dan kakek.

\section{Metode yang digunakan :}

Dalam penelitian ini digunakan pendekatan kualitatif. Bogdan dan Taylor dalam Moleong (2007:4) menyatakan, penelitian kualitatif adalah prosedur penelitian yang menghasilkan data deskriptif berupa kata-kata tertulis atau lisan dari orang-orang dan perilaku yang dapat diamati. Disini menggunakan pendekatan kualitatif karena melihat sifat dari masalah yang akan diteliti dapat berkembang secara alamiah sesuai dengan situasi dan kondisi di lapangan. Jadi dipilih pendekatan kualitatif karena ingin mengetahui subyek secara mendalam. Penelitian kualitatif memiliki sifat terbuka dalam interpretasi data yang dengan seksama dan mendeskripsikan data hasil pengamatan secara detail dilengkapi dengan catatan atau dokumentasi data penelitian. Data dihimpun dengan pengamatan yang seksama, 
mencakup deskripsi dalam konteks yang detail disertai catatan-catatan hasil wawancara yang mendalam.

Data utama dalam penelitian kualitatif adalah kata-kata dan tindakan, selebihnya adalah data tambahan seperti dokumen. Sumber data yang dimaksud dalam penelitian adalah subjek dari mana data-data diperoleh. Obyek dalam kualitatif disebut dengan social situation (situasi sosial) yang terdiri atas tiga elemen: tempat (Place), pelaku (actor) dan aktifitas (activity) yang berinteraksi secara sinergi Lofland dalam Sugiyono (2011:215). Pemilihan informan dalam penelitian ini menggunakan tehnik purposive yaitu memilih orang yang dipandang tahu dan menguasai tentang situasi sosial yang diteliti. Informan dalam penelitian ini adalah orang tua yang secara langsung mengasuh anaknya karena ditinggal ibu bekerja di luar negeri menjadi tenaga kerja wanita yang anaknya sekolah di SDN Pidodo Kecamatan Karangtengah Kabupaten Demak.

Sumber data primer diterima secara langsung dari informan yang berupa ucapanucapan, ungkapan-ungkapan, kesaksiankesaksian dari guru yang mengajar anak tersebut serta tindakan-tindakan dari subyek yang diteliti. Dalam penilitian ini data-data diperoleh dari wawancara, pengamatan kepada ayah, nenek, bibi, dan paman di desa Pidodo Kecamatan Karangtengah Kabupaten Demak selaku pengasuh anak yang ditinggal ibunya bekerja sebagai tenaga kerja wanita ke luar negeri yang anaknya sekolah di SDN Pidodo Kecamatan Karangtengah Kabupaten Demak. Yang menjadi responden dalam penelitian ini adalah keluarga TKW adalah orang tua pengganti yang memberikan penguatan pendidikan karakter pada anak dalam keluarga baik itu ayah, nenek, paman, bibi, kakak, atau kerabat atau anggota keluarga dan juga anak pada keluarga TKW di Desa Pidodo Kecamatan Karangtengah Kabupaten Demak, serta guru yang mengajar anak TKW tersebut.
Data skunder adalah data yang diperoleh secara tidak langsung dari sumbernya. Dalam penelitian ini yang dapat digolongkan data sekunder adalah data-data dari jurnal harian kelas dan buku bimbingan kelas di SDN Pidodo Kecamatan Karangtengah Kabupaten Demak.

\section{HASIL DAN PEMBAHASAN}

\section{Pola Asuh Orang Tua pada Keluarga TKW 1}

Ditinggal pergi ibu memang sangat berat, apalagi perginya tidak hanya sehari dua hari, bahkan sampai bertahun-tahun. Namun karena faktor ekonomi sehingga ibu bertekat pergi keluar negeri untuk membantu kebutuhan rumah tangga. Keluarga yang pertama didatangi adalah sebuah keluarga yang ibunya menjadi TKW di Taiwan.

Dari hasil wawancara pada informan pertama, orang tua selaku pengasuh cukup baik dalam memberikan bimbingan anak, kontrol yang sangat kuat dari orang tua sangat terlihat yaitu disuruh sekolah madrasah diajak sholat berjamaah, disuruh mengaji pada guru mengaji di kampung. Orang tua juga membuat jadwal pada anak agar dilaksanakan dengan sebaikbaiknya dan apabila tidak melaksakan jadwal akan diberi hukuman misalnya uang jajan dikurangi atau sanksi yang lain, saat merasa kesulitan dalam mengasuh anak dia selalu konsultasi pada saudara atau keluarga untuk memutuskan yang tepat untuk anak. Dalam mengambil alih pola asuh dari ibunya yang menjadi TKW di Taiwan dia membebaskan bergaul dengan siapa saja atau bebas tapi terbatas.

Selaku pengasuh anak dalam menanamkan pendidikan karakter relegius dia selalu memerintahkan pada anak untuk sekolah madrasah, sholat berjamaah dan mengaji pada kyai atau ustadz di lingkungan dia tinggal. Untuk pelajaran sekolah dia disuruh les pada guru les bersama teman-teman yang ada di kampung. 
Pendidikan karakter mandiri yang diterapkan pada keluarga ini adalah dengan cara disuruh membersihkan tubuh sendiri, menyiapkan pakaian yang akan dikenakan sesuai dengan aktifitas yang akan dilaksanakan misalnya pakaian sekolah, pakaian sepulang sekolah dan lain sebagainya semua dilakukan oleh anak sendiri dengan pantauan dan bimbingan dari nenek.

Dalam pendidikan karakter relegius disini yang paling berperan adalah nenek yang selalu memberi contoh atau teladan pada cucunya yaitu sebelum kumandang adzan maghrib sudah diajak ke mushola dilanjutkan dengan mengaji hingga menjelang isya'.

Hasil wawancara dengan guru kelas di sekolah mengatakan bahwa anak ini berperilaku baik, berangkat sekolah tepat waktu, pakaian seragam selalu benar dan rapi, selalu mengerjakan tugas bila diberi tugas oleh semua guru, dia juga selalu mengerjakan PR yang diberikan oleh guru, selalu mengerjakan tugas piket dengan tertib, dia juga anak yang jujur, masalah keagamaan yang lebih tahu adalah guru agamanya, namun kalau saya amati setiap hari dia selalu berjamaah sholat dhuhur di musholla bersama teman-teman dan semua guru, sebelum pelajaran dimulai berdoa dan membaca asmaul husna dengan baik. Mengenai orang tua memantau dan membimbing anak ini menurut saya dia juga dibimbing"

\section{Pola Asuh Orang Tua Pada Keluarga TKW 2}

Penelitian yang kedua dilakukan pada keluarga yang ditinggalkan ibu pergi ke Singapura bekerja menjadi TKW, anak yang ditinggalkan di rumah diasuh oleh ayah, kakak perempuan yang sudah berumah tangga dengan rumah bersebelahan.

Dari hasil wawancara dengan keluarga ini dapat dilihat bahwa kepemimpinan ayah bersifat otoriter, sang ayah sering memberikan hukuman pada anak ketika mengetahui anaknya melakukan sesuatu yang kurang cocok di hati ayah. Sedangkan anak lebih nyaman tinggal bersama kakak perempuan yang rumahnya berdekatan, semua keperluan anak mulai dari makan, pakaian, jajan yang menyiapkan adalah kakak perempuan.

Menurut penuturan kakaknya bahwa: "anak ini sudah kebal dengan omelan dari ayahnya, anak ini sering dimarahi oleh ayahnya. Selaku kakaknya dia tidak bisa menasehati pada adiknya secara mendalam, hanya sekedar membantu kebutuhan yang bersifat fisik saja, seperti makan dan sandang. Sedangkan yang lain itu di wilayah ayahnya".

Menurut penuturan guru kelasnya bahwa anak ini di dalam kelas sering mengalami blank pak, maksudnya kalau saya ajar sering tidak nyambung sama pelajaran yang saya sampaiakan. Sering berangkat terlambat, suka mengantuk, jarang mengerjakan tugas yang saya berikan, tugas di sekolah ataupun tugas PR tidak pernah dikerjakan, anak ini termasuk anak yang sulit dinasehati. Pernah suatu pagi saat sekolah sedang berlangsung anak ini disuruh pulang oleh ayahnya tanpa alasan yang jelas.

\section{Pola Asuh Orang Tua Pada Keluarga TKW 3}

Selanjutnya melakukan wawancara dengan bapak X ayah sambung dari siswa SDN Pidodo yang ibunya bekerja sebagai TKW di Hongkong. Sebagaimana yang telah diungkapkan oleh bapak bahwa beliau dalam mengasuh anaknya sepenuhnya diserahkan kepada ibu mertuanya yaitu nenek dari anaknya. Kemudian dalam mengasuh anak ayah hanya kadang-kadang mengunjungi anak, membelikan apa yang diinginkan anak. Dari apa yang diungkapkan oleh bapak X tersebut tampak ayah menggunakan pola asuh permisif dalam mengasuh anaknya.

Kemudian menanyakan hal tersebut kepada nenek yang setiap hari mengasuh dengan hasil bahwa nenek menyiapkan kebutuhan makan, pakaian dan uang saku pada cucunya namun nenek tidak memantau perkembangan pendidikan dan karakter cucunya seperti halnya 
saat waktunya sekolah madrasah, sholat, mengaji anak dibiarkan berjalan sendiri tanpa pantauan dari nenek. Karakter mandiri belum diajarkan oleh nenek karena cucu masih dilayani dan disiapkan semua kebutuhanya.

Menurut penuturan bibinya, anak tersebut cukup manja dan keras kepala, sukanya bermain, nonton televisi, kalau disuruh belajar banyak alasan, paling cuman buka tas dan buku di depan televisi namun tidak belajar, malah nonton TV bila diingatkan anaknya marah-marah dan ngambek, akhirnya terus diam daripada nanti perang mulut denganya.

Menurut penuturan guru sekolah yang setiap hari menghadapi anak ini mengatakan bahwa: anak ini termasuk anak yang malas sekolah, kadang tidak masuk sekolah tanpa alasan, untuk kegiatan sholat berjamaah dia kadang ikut, bila ada tugas piket dia sering menghindar atau tidak mau menjalankan tugasnya. Kalau mengerjakan PR hanya asalasalan atau tanpa mikir dan diisi sembarangan sehingga mendapat nilai nol, dia juga tidak diawasi oleh ayahnya, karena kedudukan ayahnya adalah ayah tiri sehingga merasa sungkan, tempat duduk anak ini saya pisah dengan tempat duduk dengan temanya karena sering bertengkar dengan temanya.

Dapat dilihat bahwa ayah tidak ikut mengasuh anaknya, sehingga anak diasuh oleh neneknya dan dengan bantuan orang lain. Dalam mengasuh nenek tidak memaksakan anak untuk melakukan apa yang diperintah kepada anak, kontrol terhadap anak juga lemah. Dalam hal mendampingi belajar nenek tidak pernah menyuruh ataupun mengingatkan anak, namun digantikan oleh orang lain. Semua keinginan anak selalu dituruti. Jika anak melakukan kesalahan nenek menasehati. Tidak ada reward untuk memotivasi belajar anak. Tampak bahwa pola asuh yang digunakan dalam keluarga ini adalah pola asuh permisif.

\section{Pola Asuh Orang Tua Pada Keluarga TKW 4}

Penelitian selanjutnya ditujukan pada keluarga TKW dimana keluarga ini terpaksa menjadi TKW karena sang suami meninggal dunia, anak satu-satunya dititipkan pada kakak perempuan atau bude yang sudah menjanda juga karena suami juga meninggal dunia, dalam penelitian ini dapat diketahui bahwa beliau menggunakan pengasuhan kontrol yang sangat kuat, kegiatan anak selalu diawasi diarahkan dan dipantau aeperti halnya berangkat sekolah hingga pulang selalu dalam pengawasan, orang tua juga tidak memperbolehkan anak bermain terlalu jauh karena khawatir sekolah madarasah ketinggalan, pendidikan kemandirian sudah mulai diajarkan melalui mempersiapkan perlengkapan sekolah, serta diajarkan pula menjaga kebersihan baik kebersihan tubuh dan membantu membersihkan lingkungan rumah. Pendidikan relegius juga sudah diterapkan dengan cara membimbing anak ini melakukan sholat, mengaji dan sekolah madrasah

Menurut penuturan guru kelasnya mengatakan: anak ini mudah berbaur dengan teman-teman yang lain, dia anak yang ceria sehingga banyak teman yang dekat padanya, ketika di sekolah dia berperilaku baik, berangkat sekolah tepat waktu, pakaian seragam selalu benar dan rapi, selalu mengerjakan tugas bila diberi tugas oleh semua guru, dia juga selalu mengerjakan PR yang diberikan oleh guru, selalu mengerjakan tugas piket dengan tertib, dia juga anak yang jujur, masalah keagamaan yang lebih tahu adalah guru agamanya, namun kalau saya amati setiap hari dia selalu berjamaah sholat dhuhur di musholla bersama teman-teman dan semua guru, sebelum pelajaran dimulai berdoa dan membaca asmaul husna dengan baik.

\section{Pola Asuh Orang Tua Pada Keluarga TKW 5}

Penelitian berikut dilakukan pada sebuah keluarga $\mathrm{X}$ dimana ibu dari keluarga tersebut menjadi TKW karena suami meninggal dunia, keputusan untuk menjadi TKW akhirnya dilakukan setelah beberapa tahun hidup dalam 
keadaan kekurangan ekonomi. Hasil penelitian di keluarga ini dalaha sebagai berikut:

Nenek merawat dan mengasuh cucunya sejak cucunya kelas dua Sekolah Dasar, saat itu semua keperluan cucu semua disiapkan oleh nenek, seiring berjalanya waktu cucu selalu dibimbing dan diarahkan untuk menyiapkan keperluan dirinya yaitu perlengkapan sekolah sehingga terbentuk karakter mandiri. Nenek mengajari cucu membantu yang ringan-ringan seperti menyapu lantai, atau bersih-bersih yang lain. Sang nenek juga mengajari cucu disiplin waktu dengan cara membatasi waktu bermain pendidikan relegius anak ini anak sekolah madrasah, sholat berjamaah, mengaji dan belajar di rumah.

Dalam mengasuh cucunya, sang nenek selalu mengajarkan tanggung jawab dan disiplin. Dalam hal ini yang dilakukan yaitu mengajari dan membiasakan anak untuk mempersiapkan keperluannya sendiri misalnya menyiapkan keperluan sekolah dan membiasakan anak untuk membantu pekerjaan rumah. Anak tidak dilarang untuk bermain dengan siapa saja tetapi waktu bermain yang dibatasi karena anak harus sekolah madrasah, mengaji dan belajar itu salah satu cara supaya anak dapat bertanggung jawab terhadap tugasnya. Jika anak melakukan kesalahan tidak pernah diberikan hukuman fisik tetapi diberikan nasehat.

Mernurut penuturan guru kelasnya mengatakan anak ini ketika di sekolah dia berperilaku baik, berangkat sekolah tepat waktu, pakaian seragam selalu benar dan rapi walaupun pakaian tidak sebagus dengan teman yang lain, karena ekonominya memang pas pasan, anak ini selalu mengerjakan tugas bila diberi tugas oleh semua guru, dia juga selalu mengerjakan PR yang diberikan oleh guru, selalu mengerjakan tugas piket dengan tertib, jujur. Karakter yang telah terbentuk pada anak ini adalah relegius, disiplin, mandiri, dan bertanggung jawab.

Masalah keagamaan atau relegius terlihat setiap hari dia selalu berjamaah sholat dhuhur di musholla bersama teman-teman dan semua guru, sebelum pelajaran dimulai berdoa dan membaca asmaul husna, membaca suratsurat pendek dengan baik. Mengenai orang tua memantau dan membimbing anak ini sudah baik, disiplin anak ini juga sudah disiplin, karena dia tidak pernah terlambat dalam berangkat sekolah, mandiri, anak ini sudah mandiri karena saat dia malaksanakan tugasnya dia melaksanakan dengan mandiri, bertanggung jawab anak ini sudah bertanggung jawab karena ssaat diberi tugas apapun dia bisa menyelesaikan tugas dengan baik dan bertanggung jawab.

Pengasuhan di keluarga pertama ini menggunakan pola asuh demokratis, yaitu adanya kesempatan bagi anak untuk mengemukakan pendapat dan diberi kebebasan untuk bermain dan berteman, Sesuai dengan pendapat Hourlock dalam Thoha: Pola asuh demokratis ditandai dengan adanya pengakuan orang tua terhadap kemampuan anak, anak diberi kesempatan untuk tidak bergantung pada orang tua. Menurut penelitian Alizadeh Shahla (2011:195) Mengatakan bahwa: Dalam keluarga, gaya pengasuhan secara langsung berdampak pada gejala dan perilaku anak. gaya pengasuhan yang demokratis dalam pengasuhan telah berdampak positif terhadap karakter anak, gaya pengasuhan yang demokratis dalam pengasuhan telah terbukti (berdamapak) lebih baik bagi anak, dengan mengurangi hambatan inernal dan hambatan eksternal.

Dari hasil penelitian tampak bahwa orang tua menjalankan fungsinya sebagai pelindung dan pemelihara keluarga. Fungsi tersebut telah dijalankan oleh orang tua hal tersebut terlihat dari orang tua bekerja untuk memenuhi kebutuhan anak-anaknya, mengontrol kegiatan anak serta memperhatikan perkembangan belajar anaknya. Orang tua selalu berkomunikasi dan meluangkan waktu untuk mendengarkan keluh kesah anak dan memberikan nasehat serta saran. Menurut Marry Go Setiawan (2000:69) berkomunikasi secara pribadi berarti komunikasi diadakan secara khusus dengan anak, sehingga akan dapat 
mengetahui perasaan yang sedang dialami oleh anaknya, baik perasaaan ketika anak senang, marah dan gembira

Pada keluarga TKW kedua berdasarkan hasil pemaparan dari tiga informan bahwa pola asuh keluarga ini menggunakan pola asuh otoriter. Pola asuh otoriter ditandai dengan cara mengatur anak dengan aturan-aturan yang ketat, seringkali memaksa anak untuk berperilaku seperti kehendak orang tua, kebebasan untuk bertindak atas nama diri sendiri dibatasi.

Sebuah penelitian oleh Hubbs Laura dkk. (2008:1154) dengan judul Parental Feeding Practices Predict Authoritative, Authoritarian, and Permissive Parenting Styles mengungkapkan bahwa pola asuh permisiv akan berdampak pada karakter anak.

Pada keluarga ketiga berdasarkan hasil wawancara dan observasi secara mendalam bahwa pola asuh orang tua di keluarga TKW ini mengunakan pola asuh permisiv

Untuk mengetahui secara mendalam peneliti melakukan observasi pada keluarga TKW 3. Ada yang berbeda dari apa yang diungkapkan oleh neneknya dengan apa yang terjadi di lapangan. nenek mengungkapkan jika sore hari harus pergi ke madrasah dan kalau belum pulang dari bermain harus dicari disuruh pulang untuk ke madrasah namun yang terlihat bahwa anak bermain sampai sore dan tidak dicari untuk pulang dan sekolah madrasah.

Ketika dia ditinggal ibunya orang yang mengasuh berusaha agar anak tidak rewel, mereka akan menuruti apapun yang diminta anak. Mereka akan membelikan apa saja yang diinginkan anak. Hal itu menyebabkan anak terbiasa dituruti apa yang dia inginkan. Ketika anak yang ditinggal sudah besar dia mengetahui jika ibunya mendapat gaji banyak, bagi mereka yang kurang terdidik dengan baik dia akan meminta banyak hal.

Dilihat dari pemaparan guru kelas yang setiap hari menghadapi anak ini bahwa anak ini anak yang pemalas terbukti dia terkadang tidak masuk sekolah tanpa alasan, dalam mengerjakan PR juga dikerjakan dengan asal-asalan. Dia juga sering dijauhi teman-temanya karena dia termasuk anak yang egois.

Menurut Fahmy Rahmi

Pengasuhan anak berpengaruh terhadap prestasi akademiknya. Anak anak cenderung lebih bisa meningkatkan prestasinya karena mereka mendapat kebebasan dan dihargai hasil karyanya sesuai dengan yang diharapkan.

Dalam mengasuh anak di keluarga, sang ayah tidak menerapkan reward dan punisment untuk memotivasi agar anak menjadi lebih baik. Untuk membentuk karakter anak tidak ada pembiasaan yang dilakukan oleh ayah. Dapat dikatakan bahwa ayah menggunakan pola asuh permisif dalam mendidik dan mengasuh anaknya. Hal ini sesuai dengan yang diungkapkan oleh Baumrind dalam Hadi Subroto (1997) bahwa pola asuh permisif adalah membiarkan anak bertindak sesuai dengan keinginannya, orang tua tidak memberikan hukuman dan pengendalian. Pola asuh permisif yang cenderung memberi kebebasan terhadap anak untuk berbuat apa saja sangat tidak kondusif bagi pembentukan karakter anak. Pola asuh ini sebaiknya diterapkan oleh orang tua ketika anak telah dewasa, dimana anak dapat memikirkan untuk dirinya sendiri, mampu bertanggung jawab atas perbuatan dan tindakannya.

Menurut Puspita Minda (2013) Orangtua harus dapat memberikan perlakuan yang tepat sesuai dengan perkembangan anaknya, agar anak dapat mempersepsikan tindakan yang diberikan kepadanya dengan baik sehingga dapat mengontrol dirinya. Perlakuan pada dasarnya diciptakan oleh adanya interaksi antara orangtua dan anak dalam hubungan sehari-hari yang berevolusi sepanjang waktu, sehingga orangtua akan menghasilkan anakanak sealiran, karena orangtua tidak hanya mengajarkan dengan katakata tetapi juga dengan contoh-contoh. 
Dalam keluarga ini orang tua kurang mengontrol kegiatan anaknya baik kegiatan yang berkaitan dengan pendidikan umum ataupun pendidikan agama, juga dalam berperilaku oarang tua tidak mengarahkan atau memberi teladan pada anak dengan alasan sibuk dengan pekerjaan masing-masing.

Bude yang suatu saat mengingatkan belajarnya malah menjadi perselisihan diantaranya yaitu anak ngambek, diam, atau kadang marah-marah sama yang mengingatkan, sehingga akhirnya membiarkan apa yang anak lakukan.

Pola asuh yang terapkan pada keluarga TKW 4 Berdasarkan wawancara yang peneliti lakukan bahwa pengasuhan yang dilakukan yaitu menggunakan kontrol yang kuat. Namun, tidak memaksakan anak untuk melakukan semua perintah yang diberikan kepada anak. Anak tidak diberi kebebasan dalam berteman dengan pertimbangan ditakutkan anak mendapat pengaruh buruk. Untuk membentuk kemandirian anak dengan cara menyuruh dan membiasakan anak untuk menyiapkan keperluan sekolahnya. Dalam belajar selalu ada pendampingan. Ada reward yang diberikan untuk memberikan motivasi belajar anak. Tidak ada hukuman fisik yang dilakukan jika anak melakukan kesalahan cukup dengan nasehat. Tampak bahwa pengasuhan yang digunakan yaitu menggunakan pola asuh demokratis.

Sebagaimana penelitian yang dilakukan oleh Nia Kurniasih dan Hastuti Dwi (2017:23) dengan judul penelitian "Effect of Mother's Discipline Parenting Pattern on Discipline Character of Kindergarten Children" menganalisis tentang analisis pengaruh pola asuh disiplin ibu terhadap karakter disiplin anak usia taman kanak-kanak pada TK di Kota Bogor, menyimpulkan bahwa Pendidikan dan pola asuh ibu berpengaruh dengan karakter disiplin anak. Dalam penerapan perilkau disiplin orang tua akan berdampak pada karakter disiplin anak.
Pengasuhan yang dilakukan pada keluarga TKW 5 ini Dalam mengasuh cucunya, sang nenek selalu mengajarkan tanggung jawab dan disiplin. Dalam hal ini yang dilakukan yaitu mengajari dan membiasakan anak untuk mempersiapkan keperluannya sendiri misalnya menyiapkan keperluan sekolah dan membiasakan anak untuk membantu pekerjaan rumah. Anak tidak dilarang untuk bermain dengan siapa saja tetapi waktu bermain yang dibatasi karena anak harus sekolah madrasah, mengaji dan belajar itu salah satu cara supaya anak dapat bertanggung jawab terhadap tugasnya. Jika anak melakukan kesalahan tidak pernah diberikan hukuman fisik tetapi diberikan nasehat.

Marvin W. Berkowitz (2000) mengatakan dalam jurnal yang berjudul Early Character Development and Education: Pembentukan karakter anak usia dini sangat penting. Usia anak dini di,mulai 18 bulan sampai 6 tahun. Banyak sekali hambatan untuk menbangun karakter anak usia dini ini. Untuk membentuk karakter anak usia dini perlu adanya perhatian lebih terhadap anak, perhatian pratisi terhadap pembentukan karakter, kepedulian pemangku kebijakan terhadap karakter anak, dan memperbanyak pelatihan kepada guru

Hal yang sama dilakukan oleh pakde yang ikut mengasuh dan membina saat pulang dari kerja merantau. Dia selalu menanyakan kedislipinan bagaimana sekolahnya, madarsahnya, mengaji dan belajarnya. Urusan pakaian makan sudah dipasrahkan sama neneknya. Hal senada juga dikatakan oleh nenek bahwa pakde selalu membantu dalam mengasuh keponakan terutama tentang pendidikan agamanya, dibuktikan setiap kali pulang dia langsung membimbing dan memberi teladan pada keponakanya misalnya dalam sholat berjamaah, mengaji ataupun sekolah madarasah.

Pada keluarga TKW yang ini menerapkan pola asuh demokratis, anak diberi 
kesempatan agar tidak bergantung pada orang tua, juga diberi kebebasan serta diajarkan bertanggung jawab apa yang telah dia lakukan. Tampak ketika dia di sekolah anak ini cukup bagus dalam berperilaku dan sudah menunjukkan karakter religius dibuktikan dengan kegiatan keagamaan yang ada disekolah dia mengikuti dengan baik, disiplin, dia juga anak yang disiplin karena tidak pernah terlambat dalam sekolah, mandiri anak ini sudah kelihatan mandiri saat dia mengerjakan tugas yang diberikan kepadanya. Mengenai rasa tanggung jawab anak ini sudah melaksanakan tanggung jawabnya dilihat dari tugas-tugas dan piket kelas dikerjakan dengan baik.

Gouveia M.J. \& C.Carona1dkk. (2016) Self-Compassionand Dispositional Mindfulness Are Associated with Parenting Styles and Parenting Stress: the Mediating Role of Mindful Parenting menuturkan bahwa Gaya pengasuhan yang adaptif dapat mengurangi stres dalam mengasuh anak. Anak mendapat perhatian lebih dari orangtuanya. Hal ini akan menyebabkan anak mendapatkan manfaat yang lebih besar dibandingkan dengan pola asuh lainnya.

\section{Strategi Pengasuhan Dalam Penguatan Pendidikan Karakter}

Pengasuhan anak secara sendirian oleh orang tua tanpa kehadiran ibu akan berbeda dengan keluarga yang lengkap dimana ada ayah dan ibu di dalamnya. Orang tua yang mengasuh anaknya tanpa kehadiran ibu memiliki strategi dalam pengasuhan untuk membentuk karakter kemandirian dan tanggung jawab. Strategi yang digunakan orang tua dalam pengasuhan anak adalah:

a. Menggunakan Strategi Nasehat

Nasehat sangat dibutuhkan oleh anakanak karena dengan nasehat anak bisa mendapatkan ilmu pengetahuan dan mendorongnya untuk berbuat yang baik dan luhur, nasehat yang tulus akan membekas dan berpengaruh pada anak sehingga anak bisa menjalankan apa yang dinasehatkan.

b. Menggunakan Strategi Pembiasaan

Anak merupakan amanat dari Allah SWT yang harus dirawat, didik, dan diasuh dengan sebaik-baiknya. Agar terbentuk karakter yang baik maka perlu menggunakan metode pembiasaan, dengan cara pembiasaan maka anak akan terbiasa melakukan apa yang biasa anak lakukan.

c. Menggunakan Strategi Teladan

Keteladanan dalam mendidik anak merupakan metode yang paling ampuh dan paling efektif dalam mempersiapkan dan membentuk karakter anak sesuai yang diharapkan. Keteladanan disini adalah bagaimana orang tua bisa memberi contoh terbaik dalam pandangan anak. Oleh karena itu diperlukan seorang figur untuk menjadi contoh yang akan diikuti oleh anak sebagaimana yang dilakukan pada beberapa keluarga TKW di Pidodo.

\section{d. Menggunakan Strategi Nasehat}

Nasehat sangat dibutuhkan oleh anakanak karena dengan nasehat anak bisa mendapatkan ilmu pengetahuan dan mendorongnya untuk berbuat yang baik dan luhur, nasehat yang tulus akan membekas dan berpengaruh pada anak sehingga anak bisa menjalankan apa yang dinasehatkan.

\section{Hambatan-hambatan Orang Tua Dalam Pengasuhan}

Hambatan-hambatan orang tua dalam pengasuhan anak dalam penguatan pendidikan karakter adalah hambatan dari dalam itu sendiri yaitu kurang disiplinya dalam mengasuh, tidak memberi teladan pada anak sehingga anak tidak bisa mencontoh pada orang tua yang mengasuhnya.

Hambatan eksternal orang tua dalam pengasuhan anak dalam penguatan pendidikan karakter adalah pada lingkungan dimana anak 
berinteraksi di masyarakat, atau pada orang yang lebih dewasa yang tidak memberi contoh yang baik.

\section{KESIMPULAN DAN SARAN}

Keluarga memiliki peran yang penting dan bahkan sangat menentukan dalam terbentuknya karakter anak, karena keluarga merupakan madrasah pertama dan utama dalam kehidupan. Dalam proses pengasuhan anak, setiap orang tua memiliki pola asuh yang berbeda-beda. Di SD Negeri Pidodo Kecamatan Karangtengah Kabupaten Demak terdapat tiga macam pola asuh, yaitu pola asuh otoriter, pola asuh demokratis dan pola asuh permisif.

Pola asuh pertama adalah pola asuh otoriter ditandai dengan tidak diakuinya kemampuan atau hasil karya anak, menganggap bahwa orang tua selalu benar dan anak selalu salah, terlalu ketat dalam pengasuhan, suka memberi hukuman bila anak bertindak tidak sesuai dengan kehendak orang tua. Hasil pola asuh otoriter adalah anak terlihat tertekan, pendiam serta dalam mengikuti pelajaran sering ketinggalan.

Pola asuh kedua yaitu pola asuh demokratis, ditandai dengan adanya kebebasan dari orang tua pada anak agar bisa bertindak, berkreasi, berteman dan melakukan apa yang anak sukai namun tetap dalam control yang kuat, pantauan dan bimbingan dari orang tua. Adanya dukungan, pengakuan dari orang tua tentang kemampuan anak. Hasil pola asuh demokratis disini adalah anak lebih bebas menentukan dan menyalurkan kemampuan dan keinginanya sehingga potensi yang ada di dalam anak bisa muncul dan berkembang dengan baik.

Pola asuh yang ketiga adalah pola asuh permisif. Pola asuh permisif ini orang tua cenderung membiarkan anak bertindak sesuai keinginanya tanpa adanya pemantauan, kontrol dan bimbingan dari orang tua sehingga anak berbuat apa yang anak disenangi tanpa mempunyai rasa tanggung jawab. Hasil dari pola asuh ini adalah anak cenderung berbuat seenaknya sendiri, berani membantah orang lain, dan sulit dinasehati

\section{Saran}

1. Anak adalah amanat dari Allah SWT. Asuh dan rawatlah anak dengan sebaik mungkin, kelak orang tua akan dimintai pertanggung jawaban oleh Allah SWT.

2. Orang tua sebagai pengasuh anak harus bisa menjadi figur atau teladan yang baik sehingga anak bisa meniru kebaikan orang tua yang dilakukan.

3. Bimbinglah anak, amati apa yang dia lakukan, nasehati bila melakukan kesalahan, berilah pujian bila melakukan kebaikan.

4. Guru sebagai pengganti orang tua saat anak di sekolah harus bisa mendidik membimbing dan menanamkan karakter pada anak didik.

\section{UCAPAN TERIMAKASIH}

Terimakasih diucapkan kepada Dosen Pembimbing 1 (Dr. Santoso M.Pd dosen pembimbing 2 (Dr. Slamet Utomo, M.Pd, Kaprodi PGSD Pascasarjana (Dr. Sri Utaminingsih, M.Pd) sahabat PGSD Pascasarjana Universitas Muria Kudus, Kepala Sekolah dan Dewan Guru SDN Pidodo dan semua pihak yang telah membantu penelitian ini

\section{DAFTAR PUSTAKA}

Alizadeh Shahla. Abu Tholib Mansor, Abdullah Rohani, Mansor Mariani. 2011. Relationship between Parenting 
Style and Children's Behavior Problems . Journal Asian Social Science. Volume 7.

Aziz Obi Faizal. 2017. Peranan Orang Tua Dalam Menanamkan Kedisiplinan Anak Usia Dini Pada Lingkungan Keluarga(Studi Kasus Di Dusun Kukap Desa Poncosari Kecamatan Srandakan) Jurnal.2017

Djamarah. Syaiful Bahri. 2014. Pola Asuh Orang Tua dan Komunikasi Dalam Keluarga. Rineka Cipta. Jakarta.

Elizabeth B.Hurlock. 1990. Perkembangan Anak/Child Development,Terj.Meitasari Tjandrasa. Jakarta :Erlangga.

Fahmy Rahmi. Bachtiar Nasri, Rahim Rida. 2017. Measuring and Analyzing Students' Personal Characters in Implementing Character Education. Journal of Computational and Theoretical Nanoscience.

Hadi Subroto. 1997. Mengembangkan Kepribadian Anak Balita. Gunung. Jakarta.

Hubbs Laura. Tait, Tay Seacord Kennedy, Melanie c. Page, Glade 1.Topham, Amanda w. Harrist. 2008. Parental Feeding Practices Predict Authoritative, Authoritarian, and Permissive Parenting Style. Journal the American Dietetic Association Vol. 108.

Marvin W. Berkowitz. 2000. Early Character Development and Education. Jurnal Volume 11, Nomor 1, hal. 55.

Mary Go Setiawan. 2000. Menerobos Dunia Anak. Yayasan Kalam Hidup. Bandung

Moh. Shochib . 2014. Pola Asuh Orang Tua Dalam Membantu Anak Mengembangkan Disiplin Diri. Rineka Cipta. Jakarta.

Moleong, Lexy. 2007. Metode Penelitian Kualitatif. Edisi Revisi.: PT. Remaja Rosda Karya. Bandung

Nia Kurniasih dan Hastuti Dwi. 2017. Effect of Mother's Discipline Parenting Pattern on Discipline
Character of Kindergarten Children Journal of Child Development Studies. Vol. 02. 23-34.

Nibras OR Salim. 1997. Bila Tiang Tonggak Mulai Goyah. Pustaka Hidayah. Bandung. Puspita Minda. 2013. Hubungan Antar Perlakuan Orangtua Dengan Kontrol Diri Siswa Di Sekolah. Jurnal Ilmiah Konseling. Volume 1. Hal. 330-337

Sugiyono. Metode Penelitian Kombinasi (Mixed Methods) Alfabeta Bandung.

Thoha, Chabib. 1996. Kapita Selekta Pendidikan Islam, Pustaka Pelajar. Yogyakarta. 